\title{
The Impact of the Barriers in Development of Small and Medium Enterprises
}

\section{Driton Fetaj}

driton.fetaj@unhz.eu,Pejë, Kosovo

\author{
Doi:10.5901/ajis.2015.v4n2s1p58
}

\section{Abstract}

The small and medium enterprises (SME) have a very important role in economy due to its contribution in the functioning of the country and generation of job opportunities. Development of SME-s would contribute to envisage many challenges in relation to the economic development, high level of unemployment, demographic growth and the need for structural changes. The importance of the development of small and medium enterprises is very high due to the positive effects in the local economy but in their performance face many barriers that obstruct its development. Identification of the SME barriers remains an important challenge for the owners, managers, policy makers and including the entire society; therefore in this presentation I would try to elaborate the issue of the Impact of barriers in development of the SME-s in Kosovo. The aim of this study is to review the importance of the barriers on development of SME-s in Kosovo and identification of the ways to possible minimization of them. Finalization of this study would enable its adequate addressing on the matter and would enable extraction of the necessary recommendations to further struggle the barriers that would have an impact in development of the small and medium enterprises in Kosovo.

Keywords: Enterprise, Barrier, Development, etc.

\section{Introduction}

Growth of the small and medium enterprises is a basic component for economic development. Development of enterprises absorbs young workers; increases number of tax payers, products and services at the local, regional and global markets. SME is a source of employment, concurrency, economic dynamics and innovations including stimulation of the enterprising spirit and promulgation of skills. Due to the wide spreading in the world compared to the big companies, the SME-s contributes in distribution of the incomes.

The barriers hindering business development, companies and the economy may exist as a result of government intervention or they may occur naturally in the world of business. Based on the fact that small and medium enterprises (SMEs) are the backbone of the economy, I took the initiative to address issues that are relevant and can promote the growth and success of SME-s.

However if we compare the success of SMEs in our country with other developing countries, one can say that we have made significant progress.

The basic objective of this study is to diagnose the current situation of SME-s, identify problems, obstacles, and challenges that affect the development of their activities, identifying main directions and at the same time to increase their role in the Kosovo economy.

So given the fact that it must be developed a genuine economic policy that means eliminating business barriers that are created for different institutional reasons, or other forms that appear that may lead in stimulating business activity, especially for small and medium enterprises, where their development can contribute to overcoming the many challenges associated to economic development, the effects of inequality, and high levels of unemployment, these are some of the reasons which have led me to elaborate on this topic and to give my contribution in this direction.

\section{SME-s in Kosovo and their Role in Economic Development - the History of SME-s in Kosovo}

Kosovo private economy began to develop in the second half of the 90s of the 20th century. The private enterprises have begun to be established before 1989, while significant increase in the establishment of SMEs was recorded in between the years from 1990-1993. After this period, their establishment begins to mark a significant decrease. Establishment of these enterprises is not the result of creating the necessary conditions in Kosovo, but is the period when people were deprived from work and in order to survive established their own enterprises as an alternative to personal and family 
employment. After a rapid development between the years 1985-1990, started the decrease rate of development of private business, mainly due to the installation of repressive rule in Kosovo in year 1989/1990. This decline continues during the period from 1991-1995. Such a decline culminates with the complete collapse of the private economy in Kosovo during the period from 1996-1998, when the majority of small and medium enterprises bankrupt and disappear, whereas the establishment of new enterprises almost drops to zero. In the postwar period the private economy, the small and medium businesses in Kosovo are marking an expansive development in terms of quantity but also in qualitative terms.

Table 1. The data on establishment of SME-s in Kosovo

\begin{tabular}{|ccc|}
\hline Year of the establishment & Number of enterprises & Percentage \\
\hline $1985-1990$ & 166 & 27.7 \\
$1991-1995$ & 122 & 20.3 \\
$1996-1998$ & 22 & 3.7 \\
$1999-2005$ & 290 & 48.3 \\
Total & 600 & 100.0 \\
\hline
\end{tabular}

Source: The data based on the survey by the Ministry of Trade and Industry - Department of development and private sector

According to the data presented in Table 1, we see that in the period between 1985-1990 that a total of 166 companies were registered out of the total of enterprises surveyed, while in the period from 1991 to 1995 the number of registered enterprises falls to 122 or 7.4\% less than in the previous period. In the period from 1996-1998 the number of registered enterprises were only 22 or $16.6 \%$ less than in the period between 1991-1995, or 24\% less than in the period 1985-1990.

In the post war period in Kosovo began the process to create new institutional conditions for the development of private enterprises, particularly in developing the legislation and the new institutions. In this period was evidenced a change in the structure of private enterprises developing an economic activity. It is evident the decrease of trade participation and gradual growth of the industry / manufacturing businesses and some services relevant to the current stage of the reconstruction phase in Kosovo.

\subsection{Registered Businesses in Kosovo}

According Kosovo Agency for Registration of Businesses under the Ministry of Trade and Industry, the number of SMEs registered on 31 December 2010 was over 100.015, which employed 216,799 workers, or 79.59\% of total employees in the private sector and $62.24 \%$ of total employees Kosovo. The size of SMEs in Kosovo is defined by Law. 17 no 2005 I 02-L5 and Law 18 no. 03 / L-031 to support Small and Medium Enterprises.

The number of employees is the only criteria for classification of enterprises by the size in Kosovo. This differs from EU countries, where in addition to the number of employees, the annual turnover is taken into account. The table below shows the spectrum of registered enterprises in Kosovo based on the number of workers.

Table 2. Registered Enterpises in Kosovo based on the numner of gthe workers - 2010

\begin{tabular}{|c|c|c|c|}
\hline Classification based on the size & Number of workers & Number of enterprises & Percentage in total \\
\hline Micro & $1-9$ & 102,070 & 98.37 \\
\hline Small & $10-49$ & 1,406 & 1.35 \\
\hline Medium & $50-249$ & 221 & 0.22 \\
\hline Major & Over 250 & 58 & 0.06 \\
\hline Total & & 103,755 & 100.00 \\
\hline
\end{tabular}

Source: Agency for Registration of Businesses in Kosovo

Out of the total of 103,755 enterprises: 102,070 (or 98.37\%) are micro-enterprises; 1406 (1.35 \%) are small; 221 (0.22\%) are medium and only $58(\$ 0.06 \%)$ classified as major enterprises. The overwhelming predominance of micro-enterprises has implications for SMEs Strategy. In terms of sector breakdown, SMEs are mainly concentrated in: retail (around 
50\%); transport, storage and distribution (14\%); Food products, drinks and tobacco (9\%); and hotels and restaurants (9\%).

Professional qualification of employees is of particular importance in developing businesses by activity, and indicates the emancipation of women and its participation in the labor market in general.

\section{The Barriers of SME-s in Kosovo}

This study sheds light on the general situation of businesses operating in Kosovo. To do this, I developed a survey of a representative sample of businesses involving 120 SMEs operating in Kosovo. The survey results that the majority of businesses have suffered a decline in sales. Moreover, the same suggests that a large proportion of sales of these businesses is made in the country and very little is exported; mostly the revenues are realized by household consumers. There is a continuous improvement of the internal structure and external private enterprises in Kosovo, including business activity, market, development of plans, and improvement of the management structure of the companies.

These trends are very important, since the experience of other transition countries shows that SMEs are able to react quickly to changes in the business environment and play a key role in transition period. In Kosovo, the level and speed of adjustment of economic and political environment has been unpredictable, which is indicative that structural changes within the enterprises in the future would be encouraged even more.

The survey results a number of specific obstacles for import as well as export. The development of an environment more liberal trade is also associated with the current tax policy which is being implemented. The views of the business community about this policy focused mainly on unequal treatment of businesses in Kosovo compared to other countries and relatively high disproportion of border taxes on enterprise activity that should be treated seriously about developing a more convenient tax regime, which is not stimulating the local products from the government side. This statement is based on the estimations that SMEs account for around 98\% of total registered businesses in Kosovo's economy that have an important role in economic development and employment in our country.

\section{The Main Barriers to SME Development in Kosovo}

Current literature explains that the dynamic growth of the private sector, especially SMEs, has been one of the main driving forces for economic recovery in transition economies. Moreover, expanded search related to experience in other transition economies emphasizes that the promotion of SMEs remains the single best solution for promoting economic development in the country.

Unlike most transition economies, SMEs in Kosovo are not sufficiently developed because they continue to face an unfriendly business environment. Kosovo is now facing the issues of creating new institutions and a more favorable business environment, issues which mainly derive as a result of the war, the difficulties in the transition process, privatization and institutional capacity building, etc.

As shown in the following table, SMEs in Kosovo face obstacles in their development. So, in the table below we show the obstacles to the development of SMEs, as perceived by entrepreneurs for the years 2010, 2011, 2012 and 2013. The results are presented in the average numerical scale from 1-5 (with 1 - not an obstacle and 5 - is a major obstacle). The issues of creating new institutions and a more favorable business environment, issues caused mainly as a result of the war, the difficulties in the transition process, privatization and institutional capacity building, etc., the SMEs in Kosovo face obstacles in their development.

Please Rank it based on your opinion the factors that pose an obstacle to your business: 1 - major obstacle, 2 large obstacle, 3 - a barrier, 4 - small obstacle, 5 - not an obstacle), insert the numbers on the sentence 
Table 3. Barriers of SME-S

\begin{tabular}{|l|l|l|l|l|l|l|l|}
\hline $\mathrm{Nr}$ & Nomination & 1 & 2 & 3 & 4 & 5 & $\mathrm{PP}$ \\
\hline 1 & High taxes & & & 60 & 60 & & \\
\hline 2 & $\begin{array}{l}\text { The work of taxing administration } \\
\text { (Bureaucracy) }\end{array}$ & & & 120 & & & \\
\hline 3 & $\begin{array}{l}\text { Applicable laws, inadequate and } \\
\text { insufficient }\end{array}$ & & & & 120 & & \\
\hline 4 & Legality and its implementation & 120 & & & & 120 & \\
\hline 5 & Strong concurrency & 120 & & & & & \\
\hline 6 & Corruption & 120 & & & & & \\
\hline 7 & Fiscal evasion & 120 & & & & & \\
\hline 8 & Political instability & 120 & & & & & \\
\hline 9 & Electrical Power supply & & & & 120 & 1 & \\
\hline 10 & Crime, thefts & & & 60 & 40 & 20 & \\
\hline 11 & Informal economy & 120 & & & & & \\
\hline 12 & Access to credits & & 120 & & & & \\
\hline 13 & Your managerial skills & & & & & 120 & \\
\hline 14 & Business Permission and licenses & & & & & 120 & \\
\hline 15 & $\begin{array}{l}\text { Inadequate level of professional } \\
\text { skills of the employees }\end{array}$ & & & & & 120 & \\
\hline 16 & Transport & & & & 120 & & \\
\hline 17 & $\begin{array}{l}\text { Supplying of the materials, } \\
\text { machinery and equipments }\end{array}$ & & & & & 120 & \\
\hline 18 & Lack of market & 120 & & & & & \\
\hline 19 & $\begin{array}{l}\text { Delay of payments (collection of } \\
\text { debts) }\end{array}$ & 120 & & & & & \\
\hline
\end{tabular}

Source: Report-research of SME - compiled by the author in 2014

Sketch 3. Barriers of SME in Kosovo
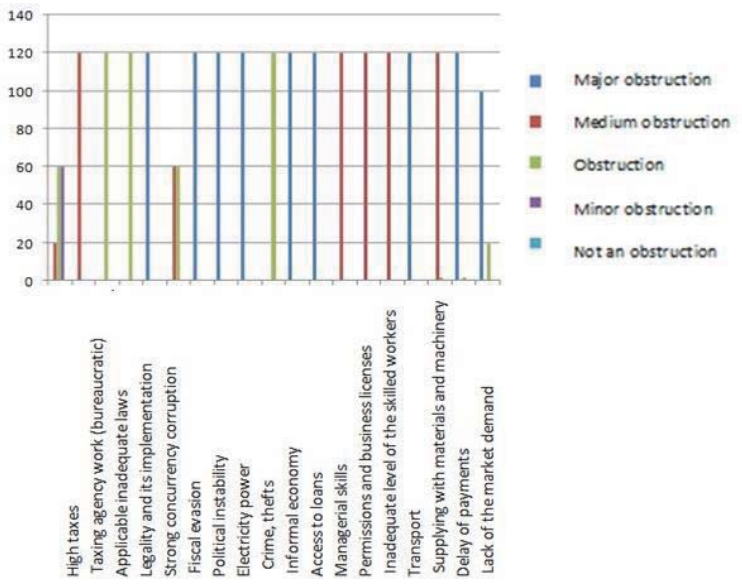

In addition, the study finds that barriers related to the lack of rule of law, for example; unfair competition, corruption, the functioning of courts, tax evasion etc., are calculated as serious barriers to Kosovo businesses and which are almost significantly increased continuously compared to the previous years. On the other hand, the barriers such as workers' skills and labor regulations, as well as infrastructure, namely: transport, electricity power are classified as less harmful to businesses.

The most serious barriers in this category is the unfair competition (mainly from tax evasion), which is evaluated at higher intensities. This is a very serious barrier as determined by all SMEs. The Unfair competition in the list is followed by corruption barriers intensity. The dominance of this barrier is not surprising considering that the international indicators of corruption, regardless of the measurement method, suggest that Kosovo continues to be one of the most corrupt countries in the region. International Transparency (in 2012), for example, in a rating from 1 to 100, where the higher the score is less corrupt society, suggests that corruption in our country is perceived to grade 34 , ranking Kosovo at the $105^{\text {th }}$ 
place, lower than in Macedonia, Montenegro and other countries of the region, except Albania. In the sequel, are ranked the road barriers, crime and theft. Even international organizations consider this phenomenon as problematic. US Department of State, for example, finds that the Kosovars, driven by unemployment and other socio-economic factors, involve in street crime, namely the theft, and so make that Kosovo is poorly ranked alongside other countries. This department documents that businesses, among others, are subject to these thefts.

\section{Conclusions}

This study sheds light on the general situation of businesses operating in Kosovo. To do this, I conducted a survey with a representative sample of businesses. From the survey results, that the majority of businesses have suffered a decline in sales. Moreover, the same suggests that a large proportion of sales of these businesses is made in the country and very little is exported; mostly the revenue is realized by the household sector and Remittance. There is a continuous improvement of the internal and external structure of private enterprises in Kosovo, including the business activity, market, development plans, and improvement of the management structure of the company. These trends are very important, since the experience of other transition countries shows that SMEs are able to react quickly to changes in the environment and play a key role in transition period.

According to the analysis revealed that for the support of SMEs in developing their operations and activities is recommended:

1. Facilitate documentation procedures for issuing administrative, professional and technical such as professional technical licenses etc.

2. Conduct an awareness campaign for the empowerment of women in the establishment and development of SMEs.

3. Establishment of policies to stimulate the financial benefits for those who have the ambition to develop the business, being in tune with enterprise business plan.

4. Creation of a guarantee fund for commercial banks that will grant loans to SMEs. This support can be given to facilitate the cost of borrowing by commercial banks facing a portion of the interest that need to take banks from lending to SME-S.

5. Direct technical support to businesses through the transfer of skills and building internal capacity of enterprises will be helping them to become more effective partner to banks and financial institutions, and helping them to participate in economic and Kosovo's political Stability.

It is much more important the issue of building a legal framework more complete and stable, which has an impact on business operations of enterprises, including implementing mechanisms to make these laws more functional and more powerful. The framework would allow the reduction of the intensity of the main barrier to business activities which have emphasized the enterprises - the lack of laws, and which framework would ensure and accelerate the important role that companies have Kosovo's economic development and security. A very important element as part of the role that the SMEs can play in the economy of Kosovo, would be the review and the broad implementation of the privatization process, including methods that have proven successful in other countries.

\section{References}

PaulBurns\&JimDewhurst, (1986), SmallBusiness in Europe, faq 22.

Ministria e Ekonomisë, (2005), Agjensiapërmbështetjen e NVM-ve, "Ndërmarrjet e vogla dhe të mesme në Shqipëri", Raporti vjetor2004, Tiranë, Faq 14.

Qeveria e Kosoves: "Ligji Nr. 02/L-5, për mbështetjen e ndërmarrjeve të vogla dhe të mesme", Prishtinë, 2005.

Sevrani k, Bahiti R, (2008), "ICT in Smalland Medium enterprises".

EuropeanCommission, March (2009), ThinkSmallFirst- Considering SME interests in policy-making

Prof. Dr. Isak MUSTAFA - Ndërmarrjanë biznesin bashkëkohor - Prishtinë, 1997.

Prof .Dr.Isa Myftari , Ekonomi e ndërmarrjes, Prishtinë, 2010, fq.33

Bridge, S, O'Neill K, andCromie, S. (2003), Understanding Enterprise, Enterpreneurship and Small Business, second edition, Palrave Macmillan

Linder J.C.,\&Cantrell S.,(2001), 'Fivebusiness-model mythsthatholdcompaniesback'. Strategy\&Leadership.

Analoui F.,\&Karami A.,(2003), 'StrategicManagement'. In smalland Medium Enterprises. ThomsonLearning.

Zoltan J. AcsandDavid B. Audretsch, "Innovation in LargeandSmallFirms," AmericanEconomicReview, , September 1988.

Ministria e Tregtisë dhe Industrisë, Hulumtimi i ndërmarrjevetë vogla dhe të mesme(NVM), Departamenti i Zhvillimit të Sektorit Privat

Ministria e tregtisë dhe industrie:" Strategjia e zhvillimit të NVM-ve në Kosovë 2013-2017", Prishtinë, 2013 
Dokumenti i Stafit Punues të Komisionit që shoqëron Komunikatën e Komisionit mbi Studimin e Fizibilitetitpër Marrëveshjen e Stabilizim Asociimit në mes Bashkimit Evropian dhe Kosovës, fq. 36

Përgjigjet e Kosovës në pyetësorin e KE për përgatitjen e Studimit të Fizibilitetit për Marrëveshjen e Stabilizim Asociimit, fq. 251

NVM Strategjia e Zhvillimit për Kosovën 2012 - 2016, fq.

Ministria e Tregtisë dhe Industrisë, agjencia për mbështetjen e NVM-ve, Raport- Hulumtimi i 800 Ndërmarrjeve të Vogla dhe të Mesme, 2011

Ministria e Tregtisë dhe Industrisë, agjencia për mbështetjen e NVM-ve, Raport- Hulumtimi i 800 Ndërmarrjeve të Vogla dhe të Mesme, 2011

Ligji Nr. 03/L-031 për Ndryshimin dhe Plotësimin e Ligjit Nr. 02/L-5 për Mbështetjen e Ndërmarrjeve të Vogla dhe të Mesme, Neni 3, http://www.kuvendikosoves.org/common/docs/ligjet/2008_03-L-031_en.pdf

Dokumenti i Stafit Punues të Komisionit që shoqëron Komunikatën e Komisionit mbi Studimin e Fizibilitetitpër Marrëveshjen e Stabilizim Asociimit në mes Bashkimit Evropian dhe Kosovës, fq. 36

Plani i Veprimit për Partneritet Evropian 2010

Të gjeturat në Raportin e Progresit të KE-së (maj - shtator 2011) 